\title{
Primary Cutaneous Hodgkin Lymphoma
}

National Cancer Institute

\section{Source}

National Cancer Institute. Primary Cutaneous Hodgkin Lymphoma. NCI Thesaurus. Code C7221.

Hodgkin lymphoma primarily involving the skin. This diagnosis can only be made when there is no evidence of Hodgkin lymphoma in the lymph nodes or other anatomic sites. Patients usually present with papules or nodular lesions. Morphologically, primary cutaneous Hodgkin lymphoma may resemble lymphomatoid papulosis or anaplastic large cell lymphoma. Immunohistochemical tissue evaluation is essential in establishing the diagnosis. --2003 